\title{
TingKat Kesiapan Kota Surakarta \\ Terhadap Dimensi Mobilitas Cerdas (SMart Mobility) SEbagai Bagian Dari Konsep Kota Cerdas (SMart City)
}

\author{
Alfariani Pratiwi \\ Program STUdi PERENCANAAN WILAYAH DAN KoTA \\ FAKULTAS TEKNIK \\ Universitas Sebelas Maret, SuraKarta \\ SOEDWIWAHJONO \\ PROGRAM STUdI PERENCANAAN WILAYAH DAN KOTA \\ FAKULTAS TEKNIK \\ UnIVERSITAS SEBELAS MARET, SURAKaRTA \\ ANa Hardiana \\ ProgRAM STUdi PERENCANAAN WILAYAH DAN KotA \\ FAKULTAS TEKNIK \\ UniVersitas SEbelas Maret, SuraKarta
}

\begin{abstract}
The city has a problem that often arises due to the construction of their own city. To prevent that, city management needs through a sustainable approach to the concept of planning. Now, the concept of smart city is developing, where several major cities in Indonesia have started implementing the concept. Surakarta be a pioneer in the use of technology of transportation commonly called Intelligent Transport Systems(ITS). Surakarta indicated to apply the concept of smart city. Together with Indosat, subsidiary of PT. Starone Partner Telecommunications (SMT) cooperate to apply the concept of smart city in Surakarta for example, e-transportation. Etransportation similar to the principle of smart mobility in the theory of smart city. Howerver not only the application of smart mobility technology, but also need to look at the aspects that provide comfort, security, and sustainability.

This study wanted to see the level of readiness of Surakarta to smart mobility dimension as part of the smart city concept. The aspects of this research are local accessibility, international accessibility, multi-modal access, information and communication technology infrastructure supporting urban mobility, sustainable transport and safety. The analytical method used in this research is the analysis technique of scoring which assess the readiness of each aspect and the overall readiness. The results showed that Surakarta belongs to the category ready but conditional on the application of smart mobility. This means Surakarta need to do several requirements either repair or procurement in some aspects. Aspects that have been prepared but has some requirements which need to be done are the aspect of local accessibility, international accessibility, multi-modal access, and information and communication technology infrastructure supporting urban mobility. Sustainable transport and safety aspects belong to the category not ready to support the implementation of smart mobility in Surakarta.
\end{abstract}

Keywords: smart city, smart mobility, smart transportation

\section{PENDAHULUAN}

Kota memiliki permasalahan yang terus bertambah dalam penataan ruangnya seiring waktu berjalan. Tidak jarang permasalahan yang muncul diakibatkan oleh pembangunan kotanya sendiri. Untuk dapat mencegah hal tersebut dibutuhkan manajemen kota melalui pendekatan konsep perencanaan yang berkelanjutan.
Saat ini tengah berkembang konsep smart city atau kota cerdas, dimana kotakota besar di Indonesia sudah mulai menerapkan konsep tersebut, namun masih belum mencapai seutuhnya. Kotakota yang disebut smart city adalah kota yang pada awalnya memiliki terobosan baru dalam penyelesaian masalah di kotanya, dan sukses meningkatkan performa kotanya (Widyaningsih,2013). 
Nijkamp et al(2009) dalam Widyaningsih (2013) mendefinisikan kota cerdas sebagai kota yang mampu menggunakan sumber daya manusia(SDM), modal sosial,dan infrastruktur telekomunikasi modern untuk mewujudkan pertumbuhan ekonomi berkelanjutan dan kualitas kehidupan yang tinggi, dengan manajemen sumber daya yang bijaksana melalui pemerintahan berbasis partisipasi masyarakat. Cohen(2011) menyebutkan bahwa kota cerdas diidentifikasikan pada 6 (enam) dimensi utama yaitu smart government (pemerintahan cerdas), smart economy (ekonomi cerdas), smart society (kehidupan sosial cerdas), smart mobility (mobilitas cerdas), smart environment (lingkungan cerdas), dan quality of live (hidup berkualitas). Dari enam (6) dimensi tersebut dalam penerapannya setiap kota dapat memfokuskan pada salah satu dimensi saja tergantung dari karakteristik kota dan urgensi permasalahan kotanya. Misalnya, Kota Copenhagen yang ada di Denmark memfokuskan diri untuk pengoptimalan bidang lingkungan. Karena hal ini, Copenhagen dianggap sebagai salah satu kota cerdas di dunia (Anonim, 2014).

Kota Surakarta merupakan salah satu kota di Indonesia yang tengah berkembang dengan permasalahan kota yang juga ikut bertambah. Kota Surakarta sendiri sudah ada indikasi untuk ikut menerapkan konsep smart city. Indosat bersama anak perusahaan PT. StarOne Mitra Telekomunikasi (SMT) berkolaborasi untuk mewujudkan konsep smart city di Kota Surakarta. Solusi yang rencananya akan diterapkan antara lain E-government, E-tax, Etransportastion, Smart tourism, Workforce Management, dan Smart Street Lightning (Hendra Sumiarsa, Division Head M2M Solution Indosat, 2015).

Dalam mendukung program prioritas (RPJM) untuk periode 20112015, Kota Surakarta melakukan inovasi penerapan teknologi di bidang transportasi yang sesuai dengan salah satu program prioritas, yaitu layanan transportasi. Inovasi yang dilakukan sekaligus membuat Kota Surakarta menjadi pioner yaitu dalam penggunaan teknologi yang biasa disebut Intelligent Transport System atau ITS. (anonim dalam implementasi "move people not car" di Kota Solo, 2013). Penerapan teknologi di bidang transportasinya sejalan dengan prinsip dimensi mobilitas cerdas pada konsep kota cerdas, yaitu mengenai sistem transportasi kota cerdas yang dihubungkan oleh teknologi informasi dan komunikasi antara moda mobil, transportasi air, kereta api, dan transportasi udara (Nurmandi ,2014, 403).

Penerapan teknologi di bidang transportasi juga menjadi langkah awal solusi E-Transportation yang sejalan dengan mobilitas cerdas sebagai bagian dari konsep kota cerdas yang akan diterapkan di Kota Surakarta. Kota Surakarta memang menjadi salah satu percontohan transportasi di Indonesia, namun Kota Surakarta dianggap juga masih memiliki permasalahan krusial transportasi yang perlu dibenahi (Kepala Sub Direktorat Lalu Lintas Angkutan Jalan (LLAJ) Kemenhub,Ahmadi, 2012).

Pada dasarnya konsep smart city tidak hanya tentang penerapan teknologi untuk mengurai permasalahan perotaan, namun juga bagaimana tata kelola di perkotaan yang mampu memberikan rasa aman, nyaman, dan berkelanjutan (Prof.Suhono Supangkat, 2015). Oleh karenanya, keinginan untuk menerapkan e-transportastion yang sejalan dengan mobilitas cerdas di Kota Surakarta bukan hanya melihat dari segi teknologi saja, namun juga perlu melihat aspek-aspek lain yang dapat mencerdaskan mobilitas kota. Penelitian ini ingin mengetahui tingkat kesiapan Kota Surakarta dalam menerapkan konsep smart city yang dilihat dari salah satu dimensinya, yaitu dimensi smart mobility (mobilitas cerdas).

\section{METODE PENELITIAN}

Ruang lingkup wilayah penelitian yaitu Kota Surakarta. Ruang lingkup pembahasannya yaitu mengenai 
mobilitas cerdas yang berfokus pada transportasi umum yang bertrayek.

Pendekatan penelitian pada penelitian ini bersifat deduktif atau biasa disebut umum-khusus yaitu peneliti menguji pertanyaan penelitian yang diturunkan dari teori. Teori terlebih dahulu dijelaskan secara eksplisit untuk kemudian dapat dilanjutkan untuk menguji pertanyaan penelitian.

Teknik analisis data yang digunakan pada penelitian ini adalah teknik analisis skoring. Data-data yang terdapat pada penelitian ini merupakan data nominal yang bersifat kualitatif, yang kemudian diubah menjadi data kuantitatif dengan cara pemberian skor(skoring). Untuk mendapatkan temuan dilakukan dengan cara membandingkan hasil skoring dengan teori dan kondisi-kondisi yang ada di Kota Surakarta.

Teknik analisis yang dilakukan antara lain: (1) Analisis skoring kesiapan dari parameter tiap variabel; (2) Analisis Kesiapan Kota terhadap Mobilitas Cerdas.

\section{HASIL DAN PEIMBAHASAN}

\section{Tingkat Kesiapan Aksesibilitas Lokal}

Tingkat kesiapan aksesibilitas lokal dilihat dari beberapa aspek yaitu, jaringan transportasi umum, tingkat kepuasan terhadap akses dan kualitas transportasi umum. Berdasarkan data yang diperoleh presentase jaringan transportasi umum yang melayanai Kota Surakarta sebesar $84,92 \%$. Nilai tersebut masuk pada karegori sangat siap, yang memiliki range nilai presentase jaringan transportasi umum yang melayani kota yaitu $>66 \%$. Menurut Gifinger (2007), sebuah kota cerdas perlu didukung dengan jaringan transportasi umum yang dapat melayani keseluruhan wilayah kota. Sementara Kota Surakarta sudah hampir memenuhi pelayanan transportasi umumnya melalui jaringan transportasi yang tersedia sebesar $84,92 \%$ dari keseluruhan luas wilayah kotanya. Hal tersebut dapat mendukung Kota Surakarta untuk mempersiapkan menjadi kota cerdas dari aspek jaringan transportasi umumnya.
Dari tingkat kepuasan dengan akses ke transportasi umum hasil kuesionernya mendapatkan jumlah skor sebesar 990 untuk tingkat kepuasan terhadap akses ke transportasi umum. Nilai tersebut berada pada range nilai 833-1167 yang berarti masuk pada kategori siap bersyarat. Sedangkan tingkat kepuasan dengan kualitas angkutan umum yang juga diperoleh dari hasil kuesioner mendapatkan jumlah skor 415. Nilai tersebut berada pada range nilai 333467, yang berarti masuk pada kategori siap, bersyarat. Menurut Giffinger (2007), aspek kepuasan terhadap akses dan kualitas transportasi umum penting dalam mendukung kemudahan untuk melakukan perpindahan dari satu tempat ke tempat lain dengan mudahnya mengakses transportasi umum dan kualitasnya yang memuaskan. Kota Surakarta sendiri masih belum dapat memuaskan dari segi akses maupun kualitas dari transportasi umumnya. Masyarakat masih merasa akses ke transportasi umum belum mudah pada setiap waktu, ada kalanya pada waktu tertentu transportasi umum sulit diakses. Begitu juga untuk kualitas transportasi umum di kota Surakarta, masyarakat pengguna transportasi umum belum merasakan kepuasan yang tinggi terhadap kualitas transportasi umum. Kepuasan yang ada saat ini antara lain dikarenakan kenyamanan sebagian moda yang sudah dilengkapi AC(Air Conditionair) dan keramahan dari kondekturnya. Namun ketidakpuasan dari masyarakat pengguna juga masih ada, antara lain ketidak- nyamanan dari dalam moda yang tidak berAC, penuh sesak penumpang saat jam puncak berangkat/ pulang sekolah maupun kerja, ketidaktepatan jadwal yang membuat lama menunggu, dan masih ditemukan moda yang sudah tidak layak. Jadi, untuk aspek tingkat kepuasan terhadap akses dan kualitas transportasi umum di Kota Surakarta bisa mendukung untuk mobilitas cerdas namun perlu melakukan beberapa perbaikan dan peningkatan kualitas (dari segi kondisi moda yang layak) serta kuantitas (dari segi jumlah modanya) dari transportasi umumnya. 
Nilai skoring tingkat kesiapan aksesibilitas lokal berdasarkan jaringan transportasi umum, kepuasan terhadap akses dan kualitas transportasi umum adalah tujuh(7) yang berarti termasuk dalam kategori siap namun memiliki syarat antara lain meningkatkan intensitas adanya transportasi umum dari segi jumlah moda dan memperbaiki kondisi transportasi umum yang sudah tidak layak yang dapat mengurangi kenyamanan penggunanya.

\section{Tingkat Kesiapan Akses Multi Moda}

Tingkat kesiapan akses multi moda dilihat dari adanya moda yang terintegrasi antara darat, rel, dan udara. Berdasarkan data yang diperoleh, di Kota Surakarta terdapat integrasi moda transportasi umum yaitu antara moda bus dengan kereta dan pesawat. Hal ini berarti pada tingkat kesiapan akses multi moda, Kota Surakarta masuk pada kategori siap, bersyarat. Menurut Besong (2007), akses multi moda terdiri dari integrasi antara moda bus dengan kereta api, integrasi moda bus dengan pesawat, dan integrasi moda kereta dengan pesawat. Di Kota Surakarta sendiri hanya terdapat integrasi antara moda bus dengan pesawat dan bus dengan kereta, belum terdapat integrasi antara moda pesawat dengan kereta, berarti moda transportasi umumya belum terintegrasi secara utuh.

Nilai skoring tingkat kesiapan akses multi moda adalah dua (2) yang berarti termasuk dalam kategori siap namun memiliki syarat untuk dapat benar-benar mendukung mobilitas cerdas. Syaratnya, kota Surakarta perlu mengadakan integrasi antara moda kereta dengan pesawat, agar semua moda transportasi umum yang ada terintegrasi satu sama lain dan memudahkan mobilitas kota yang dapat mendukung penerapan mobilitas cerdas.

\section{Tingkat Kesiapan Aksesibilitas Internasional}

Tingkat kesiapan aksesibilitas internasional dilihat dari akses menuju bandar udara dari dalam Kota Surakarta. Berdasarkan data yang diperoleh, Kota Surakarta memiliki akses menuju bandar udara melalui transportasi umum berupa bus yaitu berupa bus BST koridor 1 dan Damri. Hal ini berarti pada tingkat kesiapan aksesibilitas internasioanl Kota Surakarta masuk pada kategori siap bersyarat. Menururt Bintarto (1989) aksesibilitas perlu didukung oleh banyaknya sistem jaringan yang tersedia. Kota Surakarta memiliki jaringan transportasi yang mendukung aksesibilitas internasional yaitu berupa jaringan transportasi umum bus kota yang melayani hingga bandar udara. Namun, jaringan transportasi yang terdapat hanya dari bus kota, belum terdapat jaringan kereta api yang menuju bandar udara..

Nilai skoring tingkat kesiapan aksesibilitas internasional adalah dua (2) yang berarti termasuk dalam kategori siap namun memiliki syarat untuk dapat benar-benar mendukung mobilitas cerdas. Syaratnya, Kota Surakarta perlu melakukan perbaikan pada ketersediaan jaringan tarnsportasi umum yang menuju ke bandar udara. Jaringan yang saat ini telah ada yaitu berupa jaringan transportasi bus kota, dalam hal tersebut perlu diperbaiki dari segi ketersediaan aksesnya dari banyak titik di kota, karena yang ada saat ini, Kota Surakarta baru memiliki jaringan transportasi bus yaitu BST koridor 1 yang dapat diakses dari kota dan Damri yang dapat diakses dari terminal. Kota Surakarta juga perlu melengkapi jaringan transportasi yang berupa kereta api untuk melayani hingga bandar udara.

\section{Tingkat Kesiapan Infrastruktur Teknologi Informasi dan Komunikasi Pendukung Mobilitas}

Tingkat kesiapan infrastruktur teknologi informasi dan komunikasi pendukung mobilitas terdiri dari dua aspek yaitu ketersediaan sistem kartu cerdas dan pendapatannya serta ketersediaan informasi real time. Berdasarkan data yang diperoleh dari aspek kartu cerdas, di Kota Surakarta telah ada sistem kartu cerdas yang mendukung transportasi umum namun belum optimal. Hal tersebut masuk pada kategori siap bersyarat. Menurut Cohen (2011), keberadaan sistem kartu cerdas 
memberikan pelayanan dalam pembayaran untuk sebuah perjalanan serta memberikan pendapatan tersendiri yang diperoleh dari kartu cerdas. Sementara itu, di Kota Surakarta meskipun telah tersedia sistem kartu cerdas,namun penggunanya sangat sedikit sekali, pendapatannya pun hampir tidak ada yang berasal dari kartu cerdas, sehingga belum dapat dikatakan bahwa sistem kartu cerdas yang ada telah memberikan pelayanan dalam pembayaran untuk transportasi umum.

Sedangkan dari aspek ketersediaan informasi real time, Kota Surakarta hanya memiliki satu jenis informasi real time yaitu informasi real time mengenai kondisi lalu lintas. Hal tersebut masuk pada kategori siap bersyarat. Cohen (2011) menyebutkan bahwa mobilitas cerdas akan didukung oleh informasi real time mengenai kondisi lalu lintas kota dan informasi real time yang tersedia dari transportasi umum. Sedangkan kondisi yang ada di Kota Surakarta belum tersedia informasi real time yang tersedia dari transportasi umum.

Nilai skoring tingkat kesiapan infrastruktur teknologi informasi dan komunikasi pendukung mobilitas adalah empat (4) yang berarti termasuk dalam kategori siap namun memiliki beberapa syarat untuk dapat benar-benar mendukung mobilitas cerdas. Syaratsyarat yang perlu dipenuhi oleh Kota Surakarta pada aspek ini antara lain mengoptimalkan fungsi sistem kartu cerdas yang sudah ada dan menyediakan informasi real time dari transportasi umum,yang berfungsi untuk memberikan informasi update mengenai keberadaan moda transportasi umum yang dapat diakses oleh penggunanya.

\section{Tingkat Kesiapan Transportasi Berkelanjutan dan Aman}

Tingkat kesiapan transportasi berkelanjutan dan aman terdiri dari dua aspek yaitu aspek mobilitas hijau dan keselamatan lalu lintas. Berdasarkan data yang diperoleh, mobilitas hijau di Kota Surakarta belum didukung oleh keberadaan fasilitas sepeda berupa penyewaan sepeda dan transportasi umum yang sudah menggunakan energi bersih. Hal ini berarti pada aspek ini Kota Surakarta termasuk pada kategori tidak siap. Menurut Cohen (2011) mobilitas hijau terkait keberadaan fasilitas bersepeda di kota berupa penyewaan sepeda. Dalam hal tersebut Kota Surakarta belum sesuai dengan yang dikemukakan oleh Cohen, karena di Kota Surakarta terdapat fasilitas bersepeda yang hanya berupa parkir sepeda yang berada di beberapa titik di citywalk pada Jl.Slamet Ryadi, bukan fasilitas penyewaan sepeda. Hal itu belum cukup untuk dikatakan siap dalam aspek mobilitas hijau. Giffinger (2007) menambahkan bahwa mobilitas hijau harus didukung dengan penggunaan transportasi yang ramah lingkungan, yaitu yang menggunakan energi bersih seperti kereta listrik. Kota Surakarta belum memenuhi persyaratan tersebut, maka Kota Surakarta dalam aspek mobilitas hijau terbilang tidak siap.

Sedangkan dari aspek keselamatan lalu lintas, Kota Surakarta hanya terdapat keselamatan untuk pejalan kaki, yang berarti masuk pada kategori siap bersyarat. Dalam UU nomor 22 tahun 2009 tentang lalu lintas dan angkutan jalan, keselamatan lalu lintas dapat dipenuhi dengan adanya lajur khusus untuk transportasi umum dan fasilitas untuk pejalan kaki yang disertai kemudahan bagi penyandang cacat. Dalam hal ini Kota Surakarta masih belum memiliki lajur khusus untuk tramsportasi umum.

Nilai skoring tingkat kesiapan transportasi berkelanjutan dan aman adalah tiga (3) yang berarti termasuk dalam kategori tidak siap. Kota Surakarta dapat siap untuk mobilitas cerdasnya jika memiliki transportasi yang ramah lingkungan dan mengadakan lajur khusus untuk transportasi umum, serta mengadakan fasilitas penyewaan sepeda. Hal tersebut bermanfaat untuk mendukung mobilitas hijau\&keselamatan lalu lintas di Kota Surakarta yang dapat menjadi modal untuk menerapkan mobilitas cerdas.

Tingkat Kesiapan Dimensi Mobilitas Cerdas di Kota Surakarta 
Tingkat kesiapan mobilitas cerdas berdasarkan hasil sintesis teori dari european model dan Boyd Cohen perlu melihat lima aspek, antara lain aksesibilitas lokal, akses multi moda, aksesibilitas internasional, infrastruktur teknologi informasi \& komunikasi pendukung mobilitas, dan transportasi berkelanjutan \& aman. Kota Surakarta setidaknya telah dapat memenuhi empat aspek, yaitu aksesibilitas lokal, akses multi moda, aksesibilitas internasional, dan teknologi informasi\&komunikasinya. Ke-empat aspek tersebut terpenuhi dengan memiliki syarat. Sedangkan untuk aspek yang tidak terpenuhi adalah aspek transportasi berkelanjutan dan aman.

Hasil perhitungan skoring dari tingkat kesiapan dimensi mobilitas cerdas di Kota Surakarta adalah sembilan (9). Berdasarkan indikator tingkat kesiapan, nilai sembilan (9) berada pada range $8,4-11,7$, maka nilai sembilan (9) termasuk dalam kategori siap bersyarat dalam penerapan konsep kota cerdas dari dimensi mobilitas cerdas.

\section{KESIMPULAN}

Berdasarkan karakteristik yang telah disebutkan mengenai masing-masing aspek mobilitas cerdas di Kota Surakarta, analisis skoring tingkat kesiapan penerapan mobilitas cerdas di Kota Surakarta masih tergolong dalam kategori siap bersyarat, yang berarti pada dasarnya Kota Surakarta sudah bisa dikatakan siap dalam penerapan mobilitas cerdas, namun syarat-syarat perbaikan dan pengadaan di beberapa aspek mobilitas cerdas yang telah disebutkan di atas perlu dipenuhi.

\section{DAFTAR PUSTAKA}

Alberti, Elisa, 2011. Smart Mobility Vision Report, Deliverable of the Project Smart Metropolitan Areas Realised Through Innovation\& People,European Commision.

Cohen, Boyd. 2011. Basic Smart city Indicators : Smart city Wheel.

Giffinger, dkk . 2007. "Smart Cities: Ranking of European mediumsized cities". Vienna, Austria:
Centre of Regional Science (SRF), Vienna University of Technology.

IBM. 2008. Smarter planet.

Nijkamp, dkk . 2009. "Smart cities in Europe". 3rd Central European Conference in Regional Science CERS.

Nurmandi, Achmad. 2014. Manajemen Perkotaan : Kota Cerdas (Smart City). Yogyakarta: Jusuf Kalla School of Government Universitas Muhamadiyah Yogyakarta. 


\section{LAMPIRAN}

Tabel 1 Pembobotan Indikator

\begin{tabular}{|c|c|c|c|c|}
\hline \multirow{2}{*}{ Variabel } & \multirow{2}{*}{ Parameter } & \multicolumn{3}{|c|}{ Indikator } \\
\hline & & Sangat siap (3) & Siap bersyarat (2) & Tidak siap (1) \\
\hline \multirow{3}{*}{$\begin{array}{l}\text { Aksesibilitas } \\
\text { lokal }\end{array}$} & $\begin{array}{l}\text { Banyaknya } \\
\text { jaringan } \\
\text { transportasi } \\
\text { umum }\end{array}$ & $\begin{array}{l}\text { Sangat siap : } \\
\text { Jaringan transportasi } \\
\text { umum memenuhi } \\
>33,3 \% \text { wilayah kota }\end{array}$ & $\begin{array}{l}\text { Siap bersyarat: } \\
\text { Jaringan transportasi } \\
\text { umum memenuhi } \\
\text { 33,3\%-66,6\% wilayah } \\
\text { kota }\end{array}$ & $\begin{array}{l}\text { Tidak siap : } \\
\text { Jaringan } \\
\text { transportasi umum } \\
\text { memenuhi }<66,6 \% \\
\text { wilayah kota }\end{array}$ \\
\hline & $\begin{array}{l}\text { Kepuasan } \\
\text { dengan akses ke } \\
\text { transportasi } \\
\text { umum }\end{array}$ & $\begin{array}{l}\text { Sangat siap : } \\
\text { Kepuasan dengan } \\
\text { akses ke } \\
\text { transportasi umum } \\
\text { tinggi }\end{array}$ & $\begin{array}{l}\text { Siap bersyarat: } \\
\text { Kepuasan dengan } \\
\text { akses ke transportasi } \\
\text { umum sedang }\end{array}$ & $\begin{array}{l}\text { Tidak siap : } \\
\text { Kepuasan dengan } \\
\text { akses ke } \\
\text { transportasi umum } \\
\text { rendah }\end{array}$ \\
\hline & $\begin{array}{l}\text { Kepuasan } \\
\text { dengan kualitas } \\
\text { angkutan umum }\end{array}$ & $\begin{array}{l}\text { Sangat siap : } \\
\text { Kepuasan dengan } \\
\text { kualitas angkutan } \\
\text { umum tinggi }\end{array}$ & $\begin{array}{l}\text { Siap bersyarat: } \\
\text { Kepuasan dengan } \\
\text { kualitas angkutan } \\
\text { umum sedang }\end{array}$ & $\begin{array}{l}\text { Tidak siap : } \\
\text { Kepuasan dengan } \\
\text { kualitas angkutan } \\
\text { umum rendah }\end{array}$ \\
\hline $\begin{array}{l}\text { Akses multi } \\
\text { moda }\end{array}$ & $\begin{array}{l}\text { Ketersediaan } \\
\text { moda yang } \\
\text { terintegrasi }\end{array}$ & $\begin{array}{l}\text { Sangat siap : Moda } \\
\text { terintegrasi secara } \\
\text { penuh antara bus, } \\
\text { kereta, dan pesawat }\end{array}$ & $\begin{array}{l}\text { Siap bersyarat: Moda } \\
\text { yang terintegrasi } \\
\text { hanya bus dengan } \\
\text { kereta dan pesawat } \\
\text { atau kereta dengan } \\
\text { bus dan pesawat }\end{array}$ & $\begin{array}{l}\text { Tidak siap : Tidak } \\
\text { ada moda yang } \\
\text { terintegrasi }\end{array}$ \\
\hline $\begin{array}{l}\text { Aksesibilitas } \\
\text { Internasional }\end{array}$ & $\begin{array}{l}\text { Ketersediaan } \\
\text { akses } \\
\text { transportasi } \\
\text { umum menuju } \\
\text { bandara }\end{array}$ & $\begin{array}{l}\text { Sangat siap : Akses } \\
\text { menuju bandar } \\
\text { udara dapat melalui } \\
\text { jaringan transportasi } \\
\text { umum kereta api } \\
\text { dan bus kota }\end{array}$ & $\begin{array}{l}\text { Siap bersyarat: } \\
\text { Akses menuju bandar } \\
\text { udara hanya dapat } \\
\text { melalui salah satu } \\
\text { jaringan transportasi } \\
\text { umum dari kereta } \\
\text { atau bus kota }\end{array}$ & $\begin{array}{l}\text { Tidak siap : } \\
\text { Akses menuju } \\
\text { bandar udara tidak } \\
\text { dapat melalui } \\
\text { jaringan } \\
\text { transportasi umum }\end{array}$ \\
\hline \multirow{2}{*}{$\begin{array}{l}\text { Teknologi } \\
\text { Informasi dan } \\
\text { Komunikasi } \\
\text { Pendukung } \\
\text { Mobilitas }\end{array}$} & $\begin{array}{l}\text { Ketersediaan } \\
\text { Smart Cards dan } \\
\text { pendapatan dari } \\
\text { Smart Cards }\end{array}$ & $\begin{array}{l}\text { Sangat siap: } \\
\text { Terdapat sistem } \\
\text { kartu cerdas dan } \\
\text { berjalan optimal } \\
\text { pada transportasi } \\
\text { umum }\end{array}$ & $\begin{array}{l}\text { Siap bersyarat: } \\
\text { Terdapat sistem kartu } \\
\text { cerdas pada } \\
\text { transportasi umum } \\
\text { namun belum optimal }\end{array}$ & $\begin{array}{l}\text { Tidak siap : Tidak } \\
\text { ada sistem kartu } \\
\text { cerdas }\end{array}$ \\
\hline & $\begin{array}{l}\text { Ketersediaan } \\
\text { akses ke } \\
\text { informasi real- } \\
\text { time }\end{array}$ & $\begin{array}{l}\text { Sangat siap: } \\
\text { Terdapat informasi } \\
\text { real-time mengenai } \\
\text { kondisi lalu lintas } \\
\text { dan informasi real- } \\
\text { time yang } \\
\text { disediakan } \\
\text { transportasi umum }\end{array}$ & $\begin{array}{l}\text { Siap bersyarat: } \\
\text { Hanya terdapat salah } \\
\text { satu (informasi real- } \\
\text { time kondisi lalu } \\
\text { lintas atau posisi } \\
\text { transportasi umum) }\end{array}$ & $\begin{array}{l}\text { Tidak siap : Tidak } \\
\text { ada informasi real- } \\
\text { time yang tersedia }\end{array}$ \\
\hline \multirow[b]{2}{*}{$\begin{array}{l}\text { Transportasi } \\
\text { berkelanjutan } \\
\text { dan aman }\end{array}$} & $\begin{array}{l}\text { Ketersediaan } \\
\text { fasilitas } \\
\text { bersepeda dan } \\
\text { transportasi } \\
\text { umum yang } \\
\text { sudah } \\
\text { menggunakan } \\
\text { energi bersih }\end{array}$ & $\begin{array}{l}\text { Sangat siap : } \\
\text { terdapatnya fasilitas } \\
\text { bersepeda dan } \\
\text { transportasi umum } \\
\text { yang sudah } \\
\text { menggunakan } \\
\text { energi bersih }\end{array}$ & $\begin{array}{l}\text { Siap bersyarat: } \\
\text { hanya terdapat salah } \\
\text { satu (fasilitas } \\
\text { bersepeda atau } \\
\text { transportasi umum } \\
\text { yang sudah } \\
\text { menggunakan energi } \\
\text { bersih) }\end{array}$ & $\begin{array}{l}\text { Tidak siap : Tidak } \\
\text { terdapat fasilitas } \\
\text { bersepeda dan } \\
\text { transportasi umum } \\
\text { yang sudah } \\
\text { menggunakan } \\
\text { energi bersih }\end{array}$ \\
\hline & $\begin{array}{l}\text { Keberadaan } \\
\text { lajur khusus } \\
\text { transportasi } \\
\text { umum \& prioritas } \\
\text { keselamatan } \\
\text { pejalan kaki di } \\
\text { kota disertai } \\
\text { kemudahan bagi } \\
\text { penyandang } \\
\text { cacat }\end{array}$ & $\begin{array}{l}\text { Sangat siap : } \\
\text { Terdapat lajur } \\
\text { khusus untuk } \\
\text { transportasi umum } \\
\text { dan program } \\
\text { prioritas } \\
\text { keselamatan pejalan } \\
\text { kaki yang disertai } \\
\text { kemudahan bagi } \\
\text { penyandang cacat }\end{array}$ & $\begin{array}{l}\text { Siap bersyarat: } \\
\text { Hanya terdapat } \\
\text { salah satu (lajur } \\
\text { khusus untuk } \\
\text { transportasi umum } \\
\text { atau prioritas } \\
\text { keselamatan pejalan } \\
\text { kaki yang disertai } \\
\text { kemudahan bagi } \\
\text { penyandang cacat) } \\
\end{array}$ & $\begin{array}{l}\text { Tidak siap :Tidak } \\
\text { terdapat lajur } \\
\text { khusus untuk } \\
\text { transportasi umum } \\
\text { dan prioritas } \\
\text { keselamatan } \\
\text { pejalan kaki yang } \\
\text { disertai } \\
\text { kemudahan bagi } \\
\text { penyandang cacat }\end{array}$ \\
\hline
\end{tabular}


Alfariani dkk, Tingkat Kesiapan...

Tabel 2 Tingkat Kesiapan Aksesibilitas Lokal

\begin{tabular}{|c|c|c|c|}
\hline \multirow{2}{*}{ Parameter } & \multicolumn{3}{c|}{ Indikator } \\
\cline { 2 - 4 } & Siap (3) & Siap besyarat (2) & Tidak Siap (1) \\
\hline $\begin{array}{c}\text { Jaringan transportasi umum } \\
\text { Kepuasan dengan akses ke transportasi } \\
\text { umum }\end{array}$ & $\sqrt{ }$ & \\
\hline $\begin{array}{c}\text { Kepuasan dengan kualitas transportasi } \\
\text { umum }\end{array}$ & & $\sqrt{ }$ & \\
\hline Nilai & & $\sqrt{ }$ \\
\hline
\end{tabular}

Tabel 3 Tingkat Kesiapan Akses Multi Moda

\begin{tabular}{|c|c|c|c|}
\hline \multirow{2}{*}{ Parameter } & \multicolumn{3}{|c|}{ Indikator } \\
\cline { 2 - 4 } & Siap (3) & Siap besyarat (2) & Tidak Siap (1) \\
\hline Akses multi moda & & $\sqrt{ }$ & \\
\hline Nilai & \multicolumn{3}{|c|}{2} \\
\hline
\end{tabular}

Tabel 4 Tingkat Kesiapan Aksesibilitas Internasional

\begin{tabular}{|c|c|c|c|}
\hline \multirow{2}{*}{ Parameter } & \multicolumn{3}{|c|}{ Indikator } \\
\cline { 2 - 4 } & Siap (3) & Siap besyarat (2) & Tidak Siap (1) \\
\hline Aksesibilitas Internasional & & $\sqrt{\mid c}$ & \\
\hline Nilai & \multicolumn{3}{|c|}{2} \\
\hline
\end{tabular}

Tabel 5 Tingkat Kesiapan Infrastruktur Teknologi Informasi dan Komunikasi Pendukung Mobilitas

\begin{tabular}{|c|c|c|c|}
\hline \multirow{2}{*}{ Parameter } & \multicolumn{3}{|c|}{ Indikator } \\
\cline { 2 - 4 } & Siap (3) & Siap besyarat (2) & Tidak Siap (1) \\
\hline Kartu cerdas & & $\sqrt{ }$ & \\
\hline Informasi real time & & $\sqrt{|c|} 4$ \\
\hline Nilai & \multicolumn{3}{|c|}{4} \\
\hline
\end{tabular}

Tabel 6 Tingkat Kesiapan Transportasi Berkelanjutan dan Aman

\begin{tabular}{|c|c|c|c|}
\hline \multirow{2}{*}{ Parameter } & \multicolumn{3}{|c|}{ Indikator } \\
\cline { 2 - 4 } & Siap (3) & Siap besyarat (2) & Tidak Siap (1) \\
\hline Mobilitas hijau & & & $\sqrt{ }$ \\
\hline Keselamatan lalu lintas & & $\sqrt{\mid c} 3$ \\
\hline
\end{tabular}

Tabel 7 Tingkat Kesiapan Mobilitas Cerdas

\begin{tabular}{|c|c|c|c|}
\hline \multirow{2}{*}{ Variabel } & \multicolumn{3}{|c|}{ Indikator } \\
\cline { 2 - 4 } & Siap (3) & Siap besyarat (2) & Tidak Siap (1) \\
\hline Aksesibilitas local & & $\sqrt{ }$ & \\
\hline Akses multi moda & & $\sqrt{ }$ & \\
\hline Aksesibilitas Internasional & & $\sqrt{ }$ \\
\hline $\begin{array}{c}\text { Infrastruktur teknologi informasi dan } \\
\text { komunikasi pendukung mobilitas }\end{array}$ & & \multicolumn{2}{|}{} \\
\hline Transportasi berkelanjutan dan aman & & \multicolumn{2}{|}{} \\
\hline Nilai & & \multicolumn{2}{|}{} \\
\hline
\end{tabular}

